Journal of Original Studies

Cilt / Volume 1, Sayı / Issue 2, 2020, pp. 85-98

E - ISSN: 2717-719X

URL: https://journals.gen.tr/jos

DOİ: https://doi.org/10.47243/jos.1.2.07

Araştırma Makalesi / Research Article

\title{
AN INVESTIGATION INTO THE CHALLENGES FACING THE PLANNING OF EARLY CHILDHOOD CARE, DEVELOPMENT AND EDUCATION [ECCDE] IN GWAGWALADA AREA COUNCIL OF FCT, NIGERIA
}

\author{
Ogunode Niyi JACOB * \\ * Academic Planning Officer, Federal University Wukari, \\ NIGERIA, e-mail: lsertakan@hotmail.com \\ ORCID ID: https://orcid.org/0000-0001-8678-2485
}

Received: 26 June 2020; Accepted: 30 August 2020

\begin{abstract}
This study investigated the challenges facing the planning of Early Childhood Care, Development and Education [ECCDE] in Gwagwalada area council of FCT, Abuja, Nigeria. Descriptive research survey design was adopted for the study. The population of the study comprised sixty (60) respondents. Simple random technique was used to select the population. Questionnaire was used as data collecting instrument for the study. Test-retest was employed to determine the reliability of the instruments. Data collected were analyzed using simple percentage and Chi-square test. The result collected established that there is significant relationship between challenges and planning of early child education programme in Gwagwalada area council. The result also revealed that the following are the challenges facing the planning of early child education programme in Gwagwalada area council of FCT, Abuja, Nigeria; inadequate data/information, inadequate funding of planning, inadequate planning tools, political influence, political instability, administrative bottleneck and poor capacity development programme for educational planners. The result also showed that the implication of challenges facing the planning of early child education programme in Gwagwalada are responsible for poor implementation of early child education programme in Nigeria. The paper recommends that the government should increase the funding of early child education programme.etc.
\end{abstract}

Keywords: Challenges, Educational planning, Education 


\section{Introduction}

The Nigerian educational system consists of the basic education, post-primary education and the higher education. The Nigerian government is so passionate about the children education and developed a national curriculum and national action plan for the early child education in Nigeria.

The Nigerian early child education programme is the largest in Africa. The Nigerian early child Education programme is designed to address the physical, cognitive and psychosocial need of the Nigerian children. The early child education programme is very important for the child education development. The children in the early child education programme are expected to acquire the following skills: social skills, communication skills and learn good habit.

The general objective of the Nigeria early ducation programme includes: to prepare the child for the primary level of education; to effect a smooth transition from the home to the school; to provide adequate care and supervision for the children while their parents are at work (on the farms, in the markets. Offices, etc). The objectives also include to inculcate social norms; to inculcate in the child the spirit of enquiry and creativity through the exploration of nature, the environment, art, music and playing with toys; to develop a sense of co-operation and team spirit; learn good habits, especially good health habits, and to teach the rudiments of numbers, letters, colours, shapes, forms etc, through play (NPE,2004).

The administration and management of the Early Children Care and Development Education (ECCDE) in Nigeria is a shared responsibility between the federal, state and local government. The Federal government established Universal Basic Education Commission to coordinate, organize and manage all aspects of universal basic education programmes in Nigeria with the aims of promoting uniform policies, ensure functional and qualitative primary school education in all states across Nigeria. The Universal Basic education and the Early Children Care and Development Education (ECCDE) are under the management of the local government administration and Universal Basic Education Commission.

The Early Children Care and Development Education (ECCDE) objectives can only be achieved when there are adequate professional teachers, adequate infrastructural facilities, adequate instructional materials and adequate supervision. (Nwuche, 2018) submits that in Nigerian early childhood education today, the teacher quality is generally low.

There are many challenges facing the early child education programme in Nigeria. These problems facing early child education programme and these problem are to the poor planning of the entire educational system. The Nigerian educational sector is poorly planned from the onset. The early child education, basic education, secondary schools education and the higher education are not free from one challenges to the others. The implementation of educational programme is difficult because of planning lapses.

There are evidence to show that the Nigerian educational system is suffering from lack of effective planning. For example, the early child education according to (Ishola, 2016) majorities of the public pre-schools centres lack national curriculum and shortage of instructional materials.

The early child education in Nigeria do not have adequate professional teachers (UBEC 2018 Report). (Nwuche, 2018) also observes of inadequate teachers and inadequate infrastructural facilities. 
Global Education Monitoring (2016) report observes that there are about 150 million children ages 3 to 5 who are not accessing pre-primary school education. $80 \%$ of these children are from low income countries worldwide.

The Nigerian early child education programme is plagued with many challenges. These challenges include inadequate national curriculum, inadequate professional teachers, inadequate infrastructural facilities and unconducive learning environment.

(Christine \& Hayatu, 2014) observes that from the approach, the success of implementation may be a mirage. The approach in the first instance contradicted or violated the known rule of systematic forward planning. The impression this has created is that the nation has not learnt any lesson from the failure of the Free, Compulsory Universal Primary Education (UPE) scheme of 1976. The major cause of the failure of the UPE scheme was improper planning. It was obvious that if analysis or diagnosis of the requirements for implementation were done, the failure of UPE would have been averted.

Education planning in Nigeria is facing of many challenges. Educational planning have not been given maximum attention in Nigeria and that is the reasons for poor implementation. The early child education programme, basic education, secondary schools and the higher institutions. Moja (2000) opines that there is lack of adequate planning in the Nigerian educational system. (Ogunode, 2020) the approach employed for planning education in Nigeria is poor. (UNICEF 2017) opines that poor planning, lack of political will and underfinancing was responsible to achieve the Education for All and MDG targets. In view of this submission, the objective of this study is to find out the challenges facing the planning of Early Childhood Care, Development and Education [ECCDE] in Gwagwalada area council of FCT, Nigeria.

\section{Statement of the Problem}

(Eunice 2016) did a study which examined the extent to which instructional supervision relate to Care-Giver performance in FCT, Abuja. (Abdulrahman, 2012) looked on the Gap in the Policy and Practice of Early Childhood Care Development and Education (ECCDE). (Ishola's, 2016)' paper examined the policies, the implementation and the achievement of the educational goals with a view to gaining insight into the sustainability of this level of education for the development of the Nigerian societies while Akindele 's paper of (2011) examined the challenges of early childhood education in Nigeria. (Adeyemi, 2014) did a study that investigated the problems facing the teachers of the early child education in Nigeria.

From the above, it is clear that research on planning of early child education programme is rare and no much empirical studies on the area in Nigeria and in Gwagwalada area council of FCT, Nigeria. Based on this research gap, the purpose of the study is to investigate the challenges facing the planning of Early Childhood Care, Development and Education [ECCDE] in Gwagwalada area council of FCT, Nigeria.

\section{Research Objectives}

The objective of this study is to find out the challenges facing the planning of Early Childhood Care, Development and Education [ECCDE] in Gwagwalada area council of FCT, Nigeria. Specific objectives are to:

1. To find out if there are challenges facing the planning of early child education programme in Gwagwalada area council of FCT.

2. To find out the challenges facing challenges facing the planning of early child education programme in Gwagwalada area council of FCT.

3. To find out the implication of the challenges on the implementation of the early child education programme in Gwagwalada area council of FCT. 


\section{Research Question}

The following research question where generated to guide this study:

1. Are there challenges facing the planning of early child education programme in Gwagwalada area council of FCT?

2. What are the challenges facing the planning of early child education programme in Gwagwalada area council of FCT?

3. What is the implication of the challenges on the implementation of the early child education programme in Gwagwalada area council of FCT?

\section{Research Hypothesis}

Based on the research questions raised, one hypothesis was formulated for the study:

H0: There is no significant relationship between challenges and the planning of Early Childhood Care, Development and Education [ECCDE] in Gwagwalada area council of FCT

H1 There is significant relationship between challenges and the planning of Early Childhood Care, Development and Education [ECCDE] in Gwagwalada area council of FCT.

\section{Literature Review}

\section{Concept of Early Child Education Programme}

The national policy on education (2004) defines the early child education programme as an education given in an educational institution to children aged 3-5 plus prior to their enrollment in the primary school. The early child education is a special education programme design for the total child development. The early child education in Nigeria caters for both the rich and the poor children. The early child education programme is to provide basic literacy for the children. The official language approved for instruction in the Nigerian early child programme is local language of the host communities. The early education is planned in such a way to suit the psychological domain, cognitive domain and the affective domain of the children. It is formulated to introduce the children to former education.

The features of the early child education include the following:

(1) It is for children aged 3 to 5 years

(2) It is a foundational education

(3) It is designed for children development

(4) It is meant to aid the socialization process of the children

(5) It is only a professional teachers that are allowed to teach the children

(6)The mode of instruction is majorly by singing and playing

(7)The school environment is attractive and educative to stimulate learning

(8) The teacher-students ratio is often 1 to 20

The objectives of the early child education according to the national policy on education (2004) include:

1. Prepare the child for the primary level of education

2. Effect a smooth transition from home to school

3. Provide adequate care and supervision for the children while their parents are at work (on the farm, in the market or offices)

4. Learn good habits, especially good health habits

5. Inculcate in the child the spirit of inquiry and creativity through the exploration of nature, the environment, art, music and playing with toys and so on. 
6. Develop a sense of cooperation and team spirit

7. Inculcate social norms and.

8. Teach the rudiments of numbers, letters, colours, shapes, and forms and so on through play.

The ways to achieve the objectives of the early child education include:

(1) The government shall establish pre-primary sections in existing public schools and encouraging both community and private efforts in the provision of early childhood education;

(2) The government shall regulate and control the operation of early childhood education - to this end, the teacher pupil ratio is set at 1:25;

(3) The government shall set and monitoring a minimum standard for early childcare centres in the country;

(4) The government shall ensure that the main method of teaching in the childhood education centres will be through play, and that the curriculum of teacher education is appropriately oriented to achieve this;

(5) The government shall make provision for teacher education programmes for specialization in early childhood education. The government shall ensure that the medium of instruction will principally be the mother tongue or the language of the immediate community; and to this end: (i) developing the orthography for many more Nigerian languages; and (ii) producing textbooks in Nigerian languages; The government shall ensure full participation of communities and teachers' associations in the running and maintenance of early childhood education facilities.

The objectives of the early child education include: to prepare the children for basic education, to provide the children with a social skills, to provide the children with a safe environment, to inculcate in the child communication skills and social skills, to expos the child to learn good habits, greetings and appreciation and to teach the child the basic rudiments of numbers in mathematics (Ogunode 2020).

The important of early child education to the development of a country cannot be underestimated because the future belong to the today' children. Ogunode (2020) outlines the following as the importance of early child education:

(1) It provide a place for parent to keep their wards for education while in their official duties

(2) It provide a safety environment for the children while their parents are away

(3) It provides socialization medium for children

(4) It helps children to play with others children

(5) It provide a lively environment that promotes learning in the children.

There are two types of early child education in Nigeria. The public pre-school and the private daycare centres also known as early child education centre. The Nigerian national policy on education permits the private ownership of educational institutions in the country.

The public pre-school or early child education centre are owned by the government. The following are the feature of the public pre-school:

(1) It is owned by the government

(2) It is funded by the government

(3) The government employed the teachers in the various centre

(4) The government supervises the centres 
(5) The pre-school is free of charge

(6) The instructional materials and textbooks are provided by the government

(7) The public pre-school is aim to provide educational services for the Nigerian.

The feature of public pre-school in Nigeria include:

(1) The early education centres do not have curriculum that guided their activities.

(2) Early child education in most cities in Nigeria do not have the original copy of the National curriculum for the early child education.

(3) Most early child education centres in Nigeria do not have adequate infrastructural facilities to accommodate the children so many children are overcrowded in one class. Most public pre-school in Nigeria do not have adequate professional teachers

(4) The learning environment of most early child education centres are not attractive and do not have both indoor and outdoor playing materials.

(5) The playing grounds for the children in some public early child education centre do not have adequate playing materials; the playgrounds were not well-kept and safe for the children.

The private early child education or daycare centres are owned by the private individuals. The following are their features:

(a) It is owned by the private individual

(b) It is established to make profit

(c) It is answerable to the ministry of education that regulate it operations

(d) It is funded by the private individual and managed by school administrators.

The early child education of Nigeria is the largest in Africa. It is meant to provide quality foundational education for the children. The early child education since its reform in 2004 and fully commencement. The early child education programmer in Nigeria have come under criticism.

There have been problems with the implementation of the programme. The programme have not receive adequate supervision and issues with poor management and administration.

There have been a lot of empirical studies in the field of the Early Childhood Development (ECDS) in Nigeria and across the world. Some of the studies include that of (Akindele, 2011) whose paper examined the challenges of early childhood education in Nigeria.

In 2016 (Eunice) did a study which examined the extent to which instructional supervision relate to Care-Giver performance in, Federal Capital Territory, Abuja. The study was carried out in Abuja. The result of the research by (Eunice, 2016) showed that adequate supervision in the early childhood education assists caregivers in acquisition of new skills; help inexperienced care-givers to acquire new method of teaching and helps them identify children with learning impairment, though not done regularly. The researcher recommends that school heads should encourage frequent supervision of instruction in their various schools. Teachers who are well trained and have the knowledge of the theory and practical education should be recruited.

(Femi, 2015) did a research to evaluate the infrastructural facilities availability for the implementation of Early Childhood education. The result revealed that there is significant relationship between inadequate infrastructural facilities and early child education in Obi local government.

(Adeyemi, 2014) did a study that investigated the problems facing the teachers of the early child education in Nigeria. The result revealed the following; poor motivation, 
unconducive working environment, ineffective capacity development programme and poor supervision.

(Ogunjobi, 2012) conducted a research to find out the availability of instructional materials available in the early child education centres. Questionnaire was used for the study. The study employed the used of survey research design method. Simple sampling technique was used to select the participant in the study. Three hundred respondents were sampled in the study. The study used test-retest method to check the reliability of the instrument. Simple percentage and means was used to compute the data. The result collected disclosed that there is no significant between between the early child centres and instructional materials. The study hereby recommended that the government should provide the early child education centres with more instructional materials.

(Adebiyi,2015) identified the following as the challenges facing the early child education in Nigeria to include:

(1) Shortage of professional teachers

(2) Inadequate infrastructural facilities

(3) Shortage of instructional materials

(4) Underfunding

The Nigerian Universal Basic Education Commission (UBEC)- [The 2018 National Personnel Audit (NPA], report showed that there was a deficit of 135,319 teachers at the Early Childhood Care Development Education. Primary schools in Nigeria have a deficit of professional teachers of 139,772, the Junior Secondary Schools across the nation have a deficit of profession teachers of 2,446 . The report also put the number of primary-school-age children who are not in school at 10,193,918, which is said to be 25 percent of all primary school-age children in the country.

From the above literature reviewed, it is obvious that there is a research gap in the area of planning of Early Childhood Care, Development and Education [ECCDE] in Nigeria and in Gwagwalda in particular.

\section{Research Method}

\section{Design of the study}

A descriptive research survey design was adopted for the study.

\section{Population}

The population of the study comprised sixty (120) population who are educational planners selected from three educational institutions. Random sampling technique was employed to select the sample population of (60) in the area council.

\section{Instrument for data collection}

Questionnaire was used as data collecting instrument for the study. The questionnaire was validated by two lecturers from University of Abuja department of educational administration. The instruments were adjudged to be suitable in measuring the concept of the study at hand. Copies of the questionnaire were administered to the educational planners, headmaster and educational administrators in their respective educational institutions. The instrument was titled 'Challenges Facing Planning Early Childhood Care, Development and Education [ECCDE] Questionnaire' (CFPECCDEQ) and it was used for collecting information for the study. Three research questions and two hypotheses were used for the study. The research questions had fifteen sub-questions items. The response options with values assigned to them are: Strongly Agree (SA)...4; Agree (A)...3; Disagree (D)...2; Strongly Disagree 
(SD)...1. The questionnaire was divided into two sections. Section A and Section B. Section A was used to solicit information on bio-data of the respondents while the Section B was used to collecting information on challenges facing the planning of Early Child education programme in Gwagwalada area council of FCT, Abuja, Nigeria.

\section{Validation of the Instrument}

The researcher gave the questionnaires to professional evaluators to validate the content and makes corrections. The observation made by the evaluators were corrected before the final production of the questionnaire.

\section{Reliability of the Instrument:}

Test-retest reliability was used to determine the reliability of the instrument. The data used for computing the reliability indices were obtained from copies of the questionnaire administered on a sample of 10 educational officers in Kuje area council of FCT. The choice of Kuje area council of FCT share similar characteristics of challenges facing the planning of Early Child education programme in the area seem to be very similar. The data obtained were subjected to test for internal consistency using Pearson Product moment Correlation Coefficient statistic. It was considered appropriate in order to determine the level of homogeneity of the items. The scores of the first and second were correlated and yielded a coefficient of 0.78 and 0.68 respectively.

\section{Method of Data Collection}

The researcher administered the research questions through a research assistant who went to the various institutions and distributed to the questionnaire to the respondents. All the questionnaire distributed were collected back for the analysis of the study.

\section{Method of Data Analysis}

Statistics was used to generate frequencies from the data collected. Data collected were analyzed using frequency and percentages. Chi-square was used to test the null hypotheses. The data was presented in the Table for easy interpretation.

\section{RESULT ANALYSIS AND DISCUSSION}

Research Question one: Are there challenges facing the planning of Early Childhood Care, Development and Education [ECCDE] in Gwagwalada area council of FCT, Abuja, Nigeria?

Table 1: Responses on if there are challenges facing the planning of early child education programme.

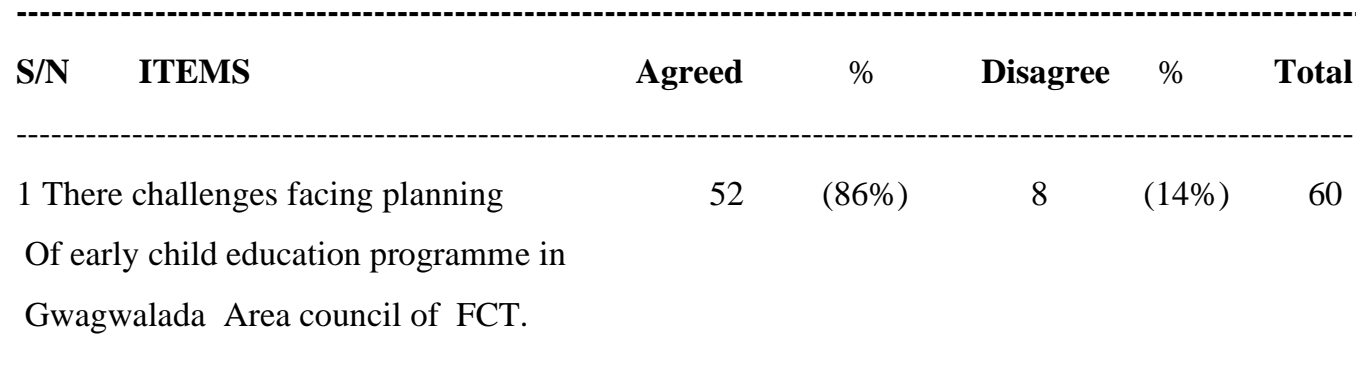

Result from research question one table one item one showed that 52(86\%) of the respondents ticked strongly agree while $8(14 \%)$ of the respondents ticked disagreed that there are challenges facing the planning of early child education programme. This implies that the 
majorities of the respondents agreed that there are challenges facing the planning of early child education programme.

Research Question two: What are the challenges facing the planning of the early child education programme in Gwagwalada area council of FCT?

Table 2. Responses on: the challenges facing challenges facing the planning of early child education programme in Gwagwalada area council of FCT.

$\mathbf{S} / \mathbf{N}$ The following are the challenges

Agreed

$\% \quad$ Disagree $\%$

Total

Facing planning of early child education

Programme in Gwagwalada Area

Council of FCT.

1. Inadequate data for planning

2. Inadequate funds for planning

3. Inadequate planning tools

4. Political influence

5. Political stability

6. Administrative Problems

7. Poor capacity development programme for planners
49

50

52

36

45

42

39

$\begin{array}{ll}(81 \%) & 21 \\ (83 \%) & 10 \\ (86 \%) & 18 \\ (60 \%) & 24 \\ (75 \%) & 15 \\ (70 \%) & 18 \\ (65 \%) & 21\end{array}$

$(19 \%)$

60

$(17 \%)$

60

$(14 \%)$

60

$(40 \%)$

60

$(25 \%)$

60

$(30 \%)$

60

$(35 \%)$

60

Result from research question two table two item one showed that $49(81 \%)$ of the respondents ticked strongly agree while $11(19 \%)$ of the respondents disagreed that inadequate data/information is one of the challenges facing the planning of Early Child education programme in Gwagwalada area council of FCT. This implies that the majorities of the respondents agreed that inadequate data/information is one of challenges facing the planning of Early Child education programme in Gwagwalada area council of FCT. (Ogunode, 2013) observes that another problem facing the planning of education in Nigeria is the problem of inadequate or reliable data to plan. One of the challenges facing the entire educational sector in Nigeria is lack of reliable and creditable data for planning purposes. The early child education, basic education, secondary school education and the higher education system do not have a reliable information and update data that can be used for planning and making decision. The data available in the various ministries and agencies of agencies saddled with the responsibilities of data management are outdate. This problem of unreliable data for planning purposes is caused by poor funding, poor capacity develop for data collecting officers and corruption

Result from research question two table two item two showed that $50(83 \%)$ of the respondents ticked agreed that inadequate funding of planning is among the challenges facing the planning of Early Child education programme in Gwagwalada area council of FCT while $10(17 \%)$ ticked disagreed that inadequate funding of planning is among the challenges facing the planning of Early Child education programme in Gwagwalada area council of FCT. This implies that the majorities of the respondents agreed that inadequate funding of planning is among challenges facing the planning of Early Child education programme in Gwagwalada area council of FCT. Inadequate planning and funding as well as the inadequacies of the monitoring processes for the implementation of national policy on education contributed to a lack of classroom space in the sub-sector. (Christine \& Hayatu, 2014) submits in their study 
that $66.6 \%$ of the teachers strongly agree that funding is inadequate. $33.4 \%$ of the respondents agree that the input of government into the UBE programme is inadequate.

Result from research question two table two item three showed that $52(86 \%)$ of the respondents ticked strongly agree while $18(14 \%)$ of the respondents went for disagree that inadequate planning tools is one of the challenges facing the planning of Early Child education programme in Gwagwalada area council of FCT. This implies that the majorities of the respondents agreed that inadequate planning tools is among the challenges facing the planning of Early Child education programme in Gwagwalada area council of FCT. This result is in line with (Christine \& Hayatu, 2014) who discovered that $73.3 \%$ of the teachers strongly agree that there are no adequate classrooms nor laboratories or workshops. $26.7 \%$ of the teachers agree that there is inadequacy of instructional aids. Teacher relied basically on blackboard, chalk and archaic textbooks.

Result from research question two table two item four showed that $36(60 \%)$ of the respondents ticked strongly agree while $24(40 \%)$ of the respondents ticked disagree that that political influence is among the challenges facing the planning of Early Child education programme in Gwagwalada area council of FCT. This implies that the majorities of the respondents agreed that political influence is among the challenges facing the planning of early child education programme in Gwagwalada area council of FCT. (Ogunode, 2013) submits that one of the greastest problem the Nigerian educational system is facing is the political influence problem. Educational policies and programme are always influenced to favour those in power. Educational planning is also faced with the problem of political interferences. Educational planners in Nigeria are always been influenced by politician or political actors in government. They influence location of educational institutions into their communities.

Result from research question two table two item five showed that 45 (75\%) of the respondents ticked strongly agree while $15(25 \%)$ respondents went for disagree that political instability is one of the challenges facing the planning of Early Child education programme in Gwagwalada area council of FCT. This implies that the majorities of the respondents agreed that political instability is among the challenges facing the planning of early child education programme. (Ogunode, 2013) observes that the nature of the democratic practices in Nigeria is affecting the educational system. A situation where there is policies instability and political instability.

Result from research question two table two item six showed that $42(70 \%)$ of the respondents ticked strongly agree while 18(30\%) went for disagree that administrative bottleneck is one of the challenges facing the planning of Early Child education programme in Gwagwalada area council of FCT. This implies that the majorities of the respondents agreed that administrative bottleneck is among the challenges facing the planning of Early Child education programme in Gwagwalada area council of FCT. (Ogunode, 2020) submits that educational planners working in the ministries are been frustrated with the various due processes which is affecting the planning programme in the country. Planning programme are subjected to various procedures from office to office before approval will be granted. Administrative bottleneck is one of the challenges that is hindering effective planning in the ministries and agencies of government.

Result from research question two table two item seven showed that $39(65 \%)$ of the respondents strongly agree and $21(35 \%)$ of the respondents disagree that poor capacity development programme of educational planners is one of the challenges facing the planning of Early Childhood Care, Development and Education [ECCDE]. This implies that the majorities of the respondents agreed that poor capacity development programme of educational planners is among the challenges facing the planning of Early Childhood Care, Development 
and Education [ECCDE] in Gwagwalada area council of FCT. This result is in line with the submission of (Ogunode, 2020) that submits that one of the major challenges facing Nigerian teachers is the poor capacity development programme. Educational planners in the various ministry of education and agencies employed for planning education programme and projects are not exposed to training programme to update their knowledge of planning. Many educational planners since joining the service of the government have never been sent for training. One of the problems educational planning working with government agencies are having in the challenge of not been given opportunities to attend workshops, seminar and conferences.

Research Question three. What is the implication of the challenges on the implementation of the Early Child education programme in Gwagwalada area council of FCT?

Table 3. Responses on: implication of the challenges on the implementation of the early child education programme in Gwagwalada area council of FCT, Nigeria.

S/N The following are the implication

Agreed

$\%$

Disagree

$\%$

Total

Of the challenges of planning of early child education

Programme in Gwagwalada Area

Council of FCT.

1. It leads to poor implementation

56

$(93 \%)$

4

$(7 \%)$

60

Of the early child education

Programme in Gwagwalada

Area council of FCT.

Result from research question three table three item one showed that 56 (93\%) of the respondents ticked strongly agreed while $4(7 \%)$ of the respondents disagreed that the implication of challenges facing the planning of early child education programme in Gwagwalada area council of FCT is responsible for the poor implementation of early child education programme in Gwagwalada area council of FCT. This implies that the majorities of the respondents agreed that the implication of challenges facing the planning of early child education programme is responsible for the poor implementation of early child education programme in Gwagwalada area council of FCT.

\section{Testing of Hypotheses}

H0: There is no significant relationship between challenges and the planning of early child education programme in Gwagwalada area council of FCT

H1 There is significant relationship between challenges and the planning of early child education programme in Gwagwalada area council of FCT

Table 5

\begin{tabular}{lllclc} 
Variables & N & Df & r-cal & r-table & Result \\
\hline $\mathrm{X}$ & 60 & 58 & 0.365 & 0.195 & Significant \\
$\mathrm{Y}$ & 60 & & & &
\end{tabular}


The table above showed that the $\mathrm{r}$ calculated is 0.365 , which is greater than the $\mathrm{t}$ calculated of value 0.195 . This means that there is significant relationship between challenges and the planning of early child education programme in Gwagwalada area council of FCT.

\section{Conclusion/ Recommendation}

This objective of this study was to find out the challenges facing the planning of Early Childhood Care, Development and Education [ECCDE] in Gwagwalada area council of FCT, Nigeria. Specific objectives are to:

1. To find out if there are challenges facing the planning of Early Childhood Care, Development and Education [ECCDE] in Gwagwalada area council of FCT, Abuja, Nigeria.

2. To find out the challenges facing the planning of early child education programme in Gwagwalada area council of FCT, Nigeria.

2. To find out the implication of the challenges on the implementation of the early child education programme in Gwagwalada area council of FCT, Nigeria.

Result was collected and analyzed and it was established that there is significant relationship between challenges and the planning of Early Childhood Care, Development and Education [ECCDE] in Nigeria. The result also revealed that the following are the challenges facing the planning of Early Child education programme in Gwagwalada area council of FCT, Abuja, Nigeria; inadequate data/information, inadequate funding of planning,inadequate funding of planning, inadequate planning tools, political influence, political instability, administrative bottleneck and pool capacity of planners.

The result also showed that the implication of challenges facing the planning of Early Child education programme is responsible for the poor implementation of Early Child education programme in Nigeria. Base on the findings, the following were therefore recommended:

- The government should increase the funding of early child education programme in Nigeria.

- The government should provide all the planning tools that educational planners need to carry out their responsibilities.

- Training and retraining programme should be organized for educational planners to improve their capacity of planning.

- The government that comes to power should have the political will to continue the planning programme initiated by the previous government

- The government should remove all forms of administrative bottleneck preventing effective planning of education in the various ministries and agencies of government

- The politician and political actors should leave the educational planners to do their job professionally and should not influenced their school sitting planning to favour their interest

- The government should support the educational planners with every political will to enhance the achievement of the planned project or programme. 


\section{REFERENCES}

AKINDELE, M. I., ... (2011).The Challenges Facing Early Childhood Care, Development and Education (ECCDE) in an Era of Universal Basic Education in Nigeria. JEMA, 7 (2), $147-168$

ADEYEMI, O. (2014). An investigation into the problems facing the teachers of the early child education in Nigeria. Unpublished Thesis.

ADEBIYI, F. (2015). Challenges facing the early child education in Nigeria. Unpublished Thesis.

ABDULRAHMAN, Y. M. (2012). The Gap in the Policy and Practice of Early Childhood Care Development and Education (ECCDE): Universal Basic Education (UBE) Component in Nigeria. International Journal of Latest Research in Humanities and Social Science (IJLRHSS) Volume 01 - Issue 03, PP. 127-133

CHRISTINE, A., \& HAYATU, S. (2014).Universal basic education (ube) in Nigeria problems and prospects in learning basic science in the upper basic : A case study of Kajuru local government area of Kaduna state.

Federal Republic of Nigeria (FRN). (2004). Implementation Guidelines for the Universal Basic Education (UBE) Programme (p.17). Abuja: Federal Ministry of Education.

Federal Republic of Nigeria (FRN). (2013) National policy on education. 6th Edition (Revised) Lagos: NERDC Press. Lagos: NERDC Press.

FEMİ, O. (2015). Evaluate the infrastructural facilities availability for the implementation of thesis.

Early Childhood Care, Development and Education [ECCDE]. Unpublished

ISHOLA, A. S., (2016).Nigerian early childhood education policies and practices for sustainability. European Journal of Research and Reflection in Educational Sciences. Vol. 4 No. 5, PP- 56-69

JENNIFER, O., NICK, C., \& CAROLINE, A. (2017). Education in Nigeria. https://wenr.wes.org/2017/03/education-in-nigeria

NWUCHE, G. M. (2018). A case for early childhood education in Nigeria. ps://www.sunnewsonline.com/a-case-for-early-childhood-education-in-nigeria/

OGUNJOBİ, A. (2012). An investigation into the availability of instructional materials available in the early child education centres in Akoko South. Unpublished Thesis.

OGUNODE, N. J. (2020). Challenges facing the planning of early childhood care education in nigeria and the ways forward. Lamb Publisher.

MOJA, T. (2000): "Nigeria Education Sector Analysis: An Analytical Synthesis of Performance and Main Issues”. New York: World Bank.

Universal Basic Education Commission. (2009). Retrieved from https://ubeconline.com/index3.php

Universal Basic Education Commission. (2014). UBE programmes. Retrieved April 8, 2014 , from http://ubeconline.com/UBEProgrammes.hmtl 
$J A C O B$ / An Investigation into the Challenges Facing the Planning of Early Childhood Care, Development and Education [ECCDE] in Gwagwalada Area Council of FCT, Nigeria 